Jurnal Konstruksi Hukum | ISSN: 2746-5055

Vol. 2, No. 1, Januari 2021 Hal. 180-185 | Tersedia online di https://www.ejournal.warmadewa.ac.id/index.php/jukonhum

DOI: https://10.22225/jkh.2.1.2991.180-185

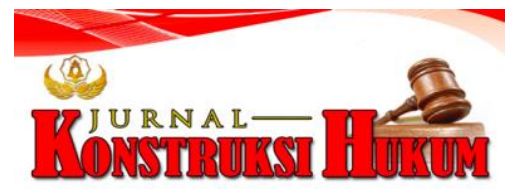

\title{
PENYELESAIAN SENGKETA PAJAK PENGHASILAN (PPH) PASAL 21 MELALUI PENGADILAN PAJAK
}

\author{
Ni Made Ina Sulastini, Ida Ayu Putu Widiati, I Nyoman Sutama \\ Fakultas Hukum Universitas Warmadewa, Denpasar-Bali, Indonesia
}

\begin{abstract}
Abstrak
Pajak merupakan unsur penting yang membantu negara dalam membiayai kegiatan pemerintahan dalam bidang pembangunan. Pelaksanaan kewajiban perpajakan tidak jarang terjadinya sengketa perpajakan yang terjadi antara wajib pajak dengan pejabat yang berwenang. Penelitian ini bertujuan untuk menjelaskan wewenang pengadilan pajak dalam menyelesaikan sengketa pajak dan menganalisis proses penyelesaian sengketa pajak penghasilan pasal 21 melalui pengadilan pajak. Penelitian yang digunakan adalah penelitian hukum normatif dengan pendekatan perundang-undangan yaitu Menelaah azas-azas hukum serta studi kasus atau kepustakaan hukum. Adapun data yang digunakan adalah sumber data hukum primer dan sekunder. Hasil penelitian menunjukkan bahwa wewenang dari Pengadilan Pajak adalah menyelesaikan sengketa pajak. Pengadilan Pajak dalam hal Banding hanya memeriksa dan memutus sengketa atas keputusan keberatan, serta dalam hal gugatan pengadilan pajak berhak memeriksa dan memutus sengketa atas pelaksanaan penagihan pajak. Selain tugas dan wewenang yang dimaksud dalam pasal 31, Pengadilan Pajak juga mengawasi kuasa hukum yang memberikan bantuan hukum kepada pihak- pihak yang bersengketa dalam sidang-sidang Pengadilan Pajak. Dalam hal terjadinya Sengketa Pajak Penghasilan Pasal 21 maka penyelesaiannya dilakukan dengan upaya hukum Keberatan apabila wajib pajak merasa tidak puas atas putusan keberatan tersebut maka wajib pajak dapat mengajukan upaya hukum banding ke Pengadilan Pajak dan wajib pajak juga dapat mengajukan upaya hukum gugatan.
\end{abstract}

Kata Kunci: Pajak; Sengketa Pajak; Pengadilan Pajak; Upaya Hukum

\begin{abstract}
Taxes are an important element that assists the state in financing government activities in the development sector. The implementation of tax obligations is not uncommon for tax disputes to occur between taxpayers and authorized officials. This study aims to explain the authority of the tax court in resolving tax disputes and to analyze the process of settling income tax disputes article 21 through the tax court. The research used is normative legal research with a statutory approach, namely examining legal principles and case studies or legal literature. The data used are primary and secondary legal data sources. The results show that the authority of the Tax Court is to resolve tax disputes. The Tax Court in the case of Appeal only examines and decides disputes over the objection decision, and in the case of a lawsuit the tax court has the right to examine and decide disputes over the implementation of tax collection. In addition to the duties and powers referred to in article 31, the Tax Court also oversees legal counsel who provides legal assistance to disputing parties in the Tax Court hearings. In the event of an Article 21 Income Tax Dispute, the settlement is carried out with legal remedies. Objection if the taxpayer is not satisfied with the objection decision, the taxpayer can file an appeal to the Tax Court and the taxpayer can also file a lawsuit.
\end{abstract}

Keywords: Tax; Tax Disputes; Tax Court; Legal effort

\section{PENDAHULUAN}

Pembangunan merupakan tanggun jawab pemerintah, banyak cara di Indonesia yang bisa digunakan untuk meningkatkan sumber dana yang akan dipergunakan sebagai biaya pembangunan juga membantu masyarakat yang menginginkan uluran tangan dari pemerintah. Salah satu cara dengan memungut pajak, banyaknya benda atau barang yang masuk dan keluar negara bisa dikenakan pajak sebagai konsekuensi dari produk yang akan dibeli atau dipasarkan. Pajak meningkatkan anggaran yang masuk untuk pembangunan disamping itu pajak dapat digunakan pemerintah untuk membatasi seseorang yang ingin menambah harta kekayaan agar memikirkan besarnya pajak yang harus dibayarkan jika ingin memiliki sebuah barang (Barus \& Alvi Syahrin, 2015). Cara yang sangat efektif yang dilakukan pemerintah dalam menekan seseorang untuk menambah kekayaannya namun tidak semua orang memikirkan besarnya 
membayar pajak ada banyak orang sukses mulai dari pegawai negeri dan pengusaha yang selalu bisa membayarkan pajak yang dikenakan karena memiliki penghasilan besar namun bagi sebagaian besar masyarakat pajak besar akan membuat mereka semakin terbebani dalam menjalani kehidupan karena bukan hanya pajak yang akan dibayarkan selama hidup tetapi mencukupi kebutuhan keluarga menjadi tugas utama.

Pajak merupakan sumber dana yang membantu pemerintah membiayai pengelauaran negara terutama dalam bidang pembangunan sumber daya manusia dan juga infrastruktur sebagaimana negara melaksaanakan tanggung jawabnya untuk mensejaterakan rakyat tanpa memikirkan pentingnya kebutuhan kelompok (Irianto, 2012). Banyak jenis pajak yang ditetapkan pemerintah dalam upaya menambah pemasukan negara salah satunya pajak penghasilan, pajak tersebut diperuntukan kepada seseorang yang memiliki penghasilan dengan jumlah tertentu (Padyanoor, 2020). Kendaraanpun di Indonesia dikenakan pajak untuk mengurangi volume kendaraan di jalan raya demi mengurangi kemacetan yang kian hari kian menjadi karena banyaknya minat masyarakat untuk memiliki kendaraan bermotor. Pemerintah menerapkan peraturan yang berisi apa saja yang akan dikenakan pajak dan jumlah pajak yang harus dibayarkan kepada pemerintah (Diamastuti, 2018). Semakin mewah dan mahalnya suatu barang otomotif semakin membengkak dana pajak yang harus dibayar. Seiring berjalannya waktu pajak di Indonesi semakin melambung tinggi demi mengurangi kemacetan membuat para miliarder menjual banyak unit kendaraan mereka demi menghindari pajak yang bisa dikatakan seharga sebuah mobil tiap bulannya. Cara efektif pemerintah dalam mengurangi banyaknya unit yang dimiliki oleh setiap orang dengan membuat wajib pajak membayar pajak yang tinggi (Kustiawan et al., 2018)

Sesuai peraturan pemerintah tentang pengaturan pajak, pemeriksaan dapat diartikan sebagai kegiatan rutin yang dilakukan pemerintah dalam memeriksa jumlah barang yang terkena pajak tiap-tiap orang agar warga Indonesia tepat waktu dalam membayar pajak namun tidak semua masyarakat aktif dalam membayar pajak ada yang menunda-nunda ada yang sampai sebuah surat sampai kerumah atas teguran karena tidak membayar pajak. Tidak semua pajak yang dipungut atau dibayarkan melainkan banyak terjadi sengketa dalam bidang perpajakan. Sengketa biasa terjadi karena banyak masyarakat yang tidak membayarkan pajaknya dalam kurun waktu yang bisa dikatakan cukup lama sehingga terjadinya sengketa pajak. Pemerintah menyadari potensi tersebut dan membuat sebuah peradilan pajak dimana setiap orang yang bermasalah dengan pajak mereka dapat membuat tuduhan dan beragumen atas pendapatnya. Semua yang berkaitan dengan pajak, persidangan pajak tidak lepas dari hukum positif yang ada diberlakukan selama ini.

Setiap orang yang memiliki masalah dengan pajak bebas melaporkan tuduhan ke pengadilan pajak dimana semua tuduhan akan diproses demi tercapainya kesepakatan atau keputusan yang dapat menjadi adil bagi pihak yang bersangkutan, juga agar para masyarakat sadar dalam membayar pajak jangan sampai karena tidak membayar pajak pemerintah mengambil sikap untuk tidak mengizinkan seseorang memiliki barang yang memiliki pajak dengan kurun waktu tertentu sampai denda atas pajak dibayarkan oleh seseorang yang mangkir dari pembayaran. Menjadikan diri contoh orang yang taat membayar pajak adalah tindakan yang menjadi panutan dikemudian hari setiap orang yang sadar betapa pentingnya bayar pajak maka akan semakin berkembang dan maju negara kita banyaknya produk yang masuk ke Indonesia akan meningkatkan laju perkembangan negara sehingga dapat melunasi hutang-hutang negara kepada negara lain. Berdasarkan kondisi ini dialkuak penelitian denagn tujuan untuk menjelaskan wewenang pengadilan pajak dalam menyelesaikan sengketa pajak dan menganalisis proses penyelesaian sengketa pajak penghasilan pasal 21 melalui pengadilan pajak

\section{METODE PENELITIAN}

Tipe penelitian ini menggunakna penelitian hukum normatif yaitu hukum kepustakaan yang mengacu pada norma hukum yang terdapat dalam peraturan Perundang-undangan (Bambang, 2002). Pendekatan Perundang-undangan dan Penelitian melalui permasalahan yang dipaparkan diatas. Pendekatan yang diguanakan adalah pendekatan perundangan-undangan dimana peneliti selalau berpatokan pada undang-undang sebagai dasar dalam menelaah masalah yang diteliti. Pendekatan kasus dilakukan guna melihat, mencatat dan memahami permasalahan yang diangkat dalam penelitian ini dengan tidak keluar dari zona hukum positif. Metode normatif dan kualitatis 
dimana dalam pengerjaannya peneliti menlaah isu hukum dengan didasari peraturan-peraturan hukum Perbankan di Indonesia (Ahmad, 2008).

\section{HASIL DAN PEMBAHASAN}

\section{Wewenang Pengadilan Pajak dalam Menyelesaikan Sengketa Pajak}

Pajak sendiri merupakan suatu bentuk yang mengikat dan memaksa yang mengharuskan seseorang dengan penghasilan tertentu untuk membayarkan sebagian penghasilannya demi pembangunan bangsa dan dipergunakan sebagai bantuan pemerintah untuk yang tidak dapat mencukupi perekonomiannya. Ada beberapa ciri-ciri wajib pajak diantaranya:

1. Warga Negara Wajib Pajak. Setiap orang dengan penghasilan tertentu dikenakan pajak dengan presentase mengikuti jumlah dana yang diperoleh setiap bulannya dan banyak barang yang dimiliki dengan nilai yang sudah seharusnya dikenakan pajak

2. Bersifat Mengikat dan Memaksa. Dalam peraturan yang dibuat pemerintah pajak dikenakan kepada orang dengan penghasilan tertentu dan harus dibayarkan tepat waktu, jika tidak membayar maka dikenakan sanksi pidana atau administratif sebagai ganjaran karena lalai

3. Hasil Pajak Dikembalikan Pada Rakyat. Semua pajak yang telah dibayarkan kepada pemerintah akan secara tidak langsung dikembalikan pada masyarakat namun cara kembali dana yang berbeda contohnya pemerintah menggratiskan SPP bagi semua murid, memberikan secara cuma-cuma biaya pengobatan semua orang dengan kartu sehat yang menggaransi setiap orang untuk melakukan perobatan dan masih banyak lagi

4. Sesuai Hukum Positif. Segala aturan dan sanksi yang diberlakukan pemerintah tentang pajak tidak melenceng dari nilai dan norma hukum positif dan telah disetujui oleh masyarakat.

Dalam perkembangannya pajak tersebut sangat erat kaitannya dengan pelaksanaan dan penyelenggaraan kepentingan umum. Pendapatan negara dari hasil pemungutan pajak kini menjadi tulang punggung untuk membiayai berbagai kegiatan negara. Hal ini dikarenakan fungsi penerimaan atau budgetair yaitu fungsi sebagai sumber penerimaan negara. Pajak berkembang seiring dengan perkembangan masyarakat, dimana ada masyarakat maka pajak hadir sebagai sumber pendanaan pemerintah dalam melaksanakan pekerjaannya. Kedudukan penting dari pajak dapat tercermin dari pajak itu sendiri. Dana yang didapat melalui warga yang bayar pajak dapat dibayarkan pemerintah untuk menutupi hutang negara dan untuk keperluan umum masyarakat demi mendapatkan pelayaran yang baik (Mardiasmo, 2003).

Pembayara pajak merupakan keharusan bagi negara, sifat wajib tersebut muncul karena undang-undang mewajibkan masyarakat yang memenuhi unsur-unsur tertentu yang diatur dalam undang-undang tersebut untuk membayar pajak, maka pemungutan pajak tersebut mempunyai kekuatan memaksa. Hal yang kemudian membedakan pajak dengan pungutan yang lain adalah bahwa pajak tersebut tidak mendapatkan kotraprestasi yang secara langsung dapat dinikmati. Hal ini dikarenakan pajak tersebut digunakan bukan untuk kepentingan pribadi individu pembayar pajak tersebut, tetapi digunakan untuk membiayai pengeluaran pemerintah. Bahwa tugas pemerintah adalah untuk mewujudkan kesejahteraan masyarakat, sehingga pajak itu sendiri akan digunakan untuk kepentingan masyarakat. Hal tersebut seringkali membuat masyarakat pembayar pajak yang tidak mengetahui pengertian pajak, fungsinya dan dasar pemungutannya mempunyai anggapan bahwa pajak tersebut tidak memberi keuntungan atau bahkan tidak bermanfaat bagi dirinya. Hal inilah yang sangat tidak baik, karena masyarakat justru akan merasa keberatan akan adanya pajak itu sendiri. Padahal pajak itu memiliki fungsi yang sangat penting bagi jalannya suatu proses pemerintahan.

Dalam upaya mendapatkan dana untuk pembangunan, pemerintah sering mendapatkan tuduhan karena ada beberapa orang merasa bahwa tidak seharusnya membayar pajak tetapi dimintai uang pajak maka terjadilah sengketa pajak yang nantinya akan dilakukan di pengadilan pajak demi mendapatkan jalan tengah antara seseorang atau pemerintah jika yang menuduh dianggap salah maka akan dikenakan sanksi administratif dan jika pemerintah maka mengganti rugi atas surat yang meminta uang pajak dibayarkan. Berbagai macam bentuk sengketa yang ada saat ini yaitu:

1. Banding

Bagi seseorang yang akan mengajukan banding wajib menunjukan keaslian surat-surat diantaranya seperti surat ketetapan pajak adalah surat ketetapan yang meliputi surat ketetapan 
pajak kurang bayar, surat ketetapan pajak kurang bayar tambahan, surat ketetapan pajak nihil, atau surat ketetapan pajak lebih bayar. Kadangkala terjadi selisih perhitungan pajak yang terutang menurut wajib pajak dan pihak kantor pelayanan pajak. Terhadap hal ini wajib pajak dapat mengajukan keberatan hanya kepada Direktur Jenderal Pajak. Keberatan diajukan dalam jangka waktu 3 bulan sejak tanggal dikirim surat ketetapan pajak atau sejak tanggal pemotongan atau pemungutan pajak secara tertulis. Keberatan diajukan dalam Bahasa Indonesia dengan mengemukakan jumlah pajak yang terutang, jumlah pajak yang dipotong atau dipungut, atau jumlah rugi menurut penghitungan wajib pajak dengan disertai alasan yang menjadi dasar penghitungan

2. Gugatan

Proses keberatan seseorang dalam membayar pajak proses ini merupakan kelanjutan dari proses keberatan kepada Dirjen Pajak, perkara gugatan merupakan perkara yang diajukan wajib pajak atau penanggung pajak. Proses panjang yang terjadi saat diadakannya pemutusan perkara dipengadilan. Seperti persidangan pada umumnya pengadilan hanya memutuskan banding serta mengawasi pihak yang melakukan banding tentang dana yang diperoleh saat mengikuti sidang (Paramitra, 2017). Dalam proses membayar pajak seseorang diwajibkan melunasi pajak yang dikenakan pada nya dan mau tidak mau harus membayar serta jika ada pajak bulan -bulan sebelumnya yang belum terbayarkan maka harus segera dibayarkan karena jika menunda lebih lama maka akan dikenakan sanksi administratif dan bahkan pidana karena lalai dalam membayar pajak serta ada unsur kesengajaan sudah tahu pajak belum dibayar tetapi sengaja menunda pembayaran. Pada umumnya sengketa pajak terjadi karena adanya rasa tidak terima karena harus membayar pajak namun perlu disadari pemerintah telah menetapkan peraturan mengenai jumlah dan nilai pajak seseuai dengan barang tertentu tetapi ketidakpedulian seseorang akan peraturan membuat keinginannya membeli banyak produk atau barang meningkat tanpa memikirkan besar biaya pajak yang nantinya akan dibayarkan.

\section{Proses Penyelesaian Sengketa Pajak Penghasilan Pasal 21 Melalui Pengadilan Pajak}

Dana yang di dapat pemerintah melalui wajib pajak selain untuk pembangunan negara juga dipergunakan sebagai mendanai para pensiunan yang sudah tidak bisa menggunakan raganya demi menjaga tanah air, mulai dari kesehatannya, keluarganya, biaya sehari-hari, asuransi serta keperluan lain sebagai rasa terimakasih karena telah mengorbankan banyak waktunya untuk bekerja demi keamanan negara. Namun tidak semua pensiunan merasakan hasil tersebut membuat banyaknya pengaduan yang datang ke pusat meminta pemerataan penghasilan dari sanak keluarga mereka yang pensiun. Menurut Ilyas, (2013) Ada dua cara yang dapat diambil dalam upaya mendapatkan pemerataan penghasilan yaitu melalui jalur gugatan yang dilakukan oleh wajib pajak kepada pemerintah dan langsung mengadukan kepada Direktorat Jendral Pajak ke kantor pelayanan pajak. Tata cara pemungutan pajak di Indonesia yaitu Self Assessment System, yaitu suatu sistem perpajakan yang memberi kepercayaan kepada Wajib Pajak untuk memenuhi kewajiban dan hak perpajakannya yang kedua Official Assessment System, yaitu inisiatif untuk memenuhi kewajiban perpajakan, ketiga sistem perpajakan dimana pihak ketiga mendapat tugas dan kepercayaan untuk memotong atau memungut suatu persentase pajak tertentu, terhadap jumlah pembayaran atau transaksi yang dilakukannya dengan penerima pengahasilan, yaitu Wajib Pajak (Ayu Noviani Hanum, 2005).

Adapun upaya yang dilakukan seseorang demi menyelesaikan permasalahan pajak yaitu:

1. Upaya Hukum Keberatan. Ketika wajib pajak memperoleh suatu Surat Ketetapan Pajak dan merasa tidak puas atas ketetapan pajak dimaksud, maka Wajib Pajak dapat mengajukan upaya hukum dengan nama keberatan. ketentuan Pasal 25 UU KUP, upaya hukum keberatan diajukan ke Direktorat Jendral Pajak yaitu ke Kantor Pelayanan Pajak (KPP) tempat dimana Wajib Pajak terdaftar.

2. Upaya Hukum Banding. Dalam pelaksanaan undang-undang perpajakan dimungkinkan adanya upaya hukum dengan nama banding apabila Wajib Pajak tetap merasa tidak puas atas keputusan keberatan yang telah dikeluarkan oleh Direktur Jendral Pajak. Artinya, terhadap surat keputusan keberatan yang diterbitkan akan menjadi dasar untuk diajukan upaya hukum banding ke pengadilan. Pengadilan Pajak yang dimaksud dengan banding adalah upaya hukum yang dapat dilakukan oleh Wajib Pajak atau penanggung pajak terhadap suatu 
keputusan yang dapat diajukan banding berdasarkan peraturan perundang-undangan perpajakan yang berlaku. Apabila wajib pajak masih merasa belum puas atas keputusan keberatan yang dikeluarkan fiskus, maka upaya hukum berikutnya dengan mengajukan banding.

3. Upaya Hukum Gugatan. Selain upaya hukum banding yang dapat diajukan ke pengadilan pajak, Wajib Pajak juga dapat mengajukan upaya hukum gugatan. Gugatan adalah upaya hukum yang dapat dilakukan oleh Wajib Pajak atau penanggung pajak terhadap pelaksanaan penagihan pajak atau terhadap keputusan yang dapat diajukan gugatan berdasarkan peraturan perundang-undangan perpajakan yang berlaku.

Penyelesaian sengketanya dapat diawali dengan Upaya Keberatan yang diajukan ke Direktorat Jendral Pajak yaitu ke Kantor Pelayanan Pajak (KPP) tempat dimana Wajib Pajak terdaftar. Apabila dalam hal Upaya Keberatan hasil dari Keputusan Keberatan tidak memuaskan maka dapat mengajukan Banding ke Pengadilan Pajak. Selain Upaya Banding wajib pajak juga dapat mengajukan

Gugatan ke Pengadilan Pajak

\section{SIMPULAN DAN SARAN}

\section{Simpulan}

Dari hasil anlaisi data penelitian, dapat disimpulkan bahwa tugas dan wewenang dari Pengadilan Pajak adalah menyelesaikan sengketa pajak. Pengadilan Pajak dalam hal Banding hanya memeriksa dan memutus sengketa atas keputusan keberatan, serta dalam hal gugatan pengadilan pajak berhak memeriksa dan memutus sengketa atas pelaksanaan atas penagihan Pajak. Pengadilan Pajak juga mengawasi kuasa hukum yang memberikan bantuan hukum kepada pihakpihak yang bersengketa dalam sidang-sidang Pengadilan Pajak, yang kedua Jika wajib pajak merasa keberatan atas pajak yang ditentukan oleh pemerintah maka dapat mengajukan gugatan yang ditujukan kepada Direktorat Jendral Pajak dengan melengkapi syarat-syarat seperti menunjukan keaslian buku pajak dan apabila kurang merasa adil maka dapat melanjutkan pengaduan ke pengadilan pajak

\section{Saran}

Adapun yang menjadi saran yaitu diharapkan kepada lembaga pengadilan pajak agar memperbaiki mekanisme sidang di luar tempat kedudukan juga dapat menjadi pilihan yang bijak. Pertimbangan mengenai kualitas dan kuantitas sumber daya Hakim, Panitera dan tenaga pengadilan lainnya ini juga berlaku dalam hal apa bila akan ditambahkan letak Pengadilan Pajak di berbagai daerah di Indonesia, yang kedua Apa bila lembaga keberatan sangat penting keberadaannya khususnya dalam upaya mempercepat penyelesaian sengketa pajak maka lembaga tersebut harus betul-betul mampu menunjukkan eksistensinya sebagai lembaga yang mampu memberi penyelesaian sengketa yang obyektif. Pemutus harus menjunjung tinggi integritas moral sehingga mampu menghasilkan keputusan yang adil.

\section{DAFTAR PUSTAKA}

Ahmad, B. (2008). Metode Penelitian Hukum. Pustakasetia.

Ayu Noviani Hanum. (2005). Permasalahan Pajak Indonesia. Jurnal Value Added, 2(1), 1-9.

Bambang, W. (2002). Penelitian Hukum dalam Praktek. Sinar Grafika.

Barus, R. M., \& Alvi Syahrin, S. A. (2015). Pertanggungjawaban Pidana Illegal Logging (Pembalakan Liar) Sebagai Kejahatan Kehutanan. USU Law Journal, 3(2), 106-114.

Diamastuti, E. (2018). Ke (Tidak) Patuhan Wajib Pajak: Potret Self Assessment System. Jurnal Ekonomi Dan Keuangan, 20(3), 280-304.

Ilyas, W. B. (2013). Hukum Pajak. Salemba Empat.

Irianto, E. S. (2012). Politik Per-pajakan, Membangun demokrasi Negara. Aswaja Pressindo.

Kustiawan, M., Solikin, I., \& Zulhaimi, H. (2018). Perguruan Tinggi Sebagai Role Model Kepatuhan Bendaharawan Pemerintah Dalam Pemotongan dan Pemungutan Pajak Penghasilan. Jurnal Aset (Akuntansi Riset), 10(2), 177-188.

Mardiasmo. (2003). Perpajakan. Cv Andy Offset.

Padyanoor, A. (2020). Kebijakan Pajak Indonesia Menanggapi Krisis COVID-19: Manfaat bagi Wajib Pajak. EJurnal Akuntansi, 30(9), 2216-2230. 
Jurnal Konstruksi Hukum

Vol. 2, No. 1, 2021

Paramitra, E. (2017). Akibat Hukum Perjanjian Perkawinan yang Tidak Disahkan oleh Pegawai Pencatat Perkawinan. Jurnal Reporetorium, 4(2), 32-38. 